$\mathrm{A} \mathrm{J}_{\cos } \mathrm{H}$

Received : 25.07.2017

Revised : 05.11.2017

Accepted : 12.11.2017

Members of the Research Forum

Associated Authors:

${ }^{1}$ Department of Horticulture,

Faculty of Agriculture,

Annamalai University,

ANNAMALAI NAGAR (T.N.)

INDIA

Author for correspondence :

K. RAMKUMAR

Department of Horticulture,

Faculty of Agriculture,

Annamalai University,

ANNAMALAI NAGAR (T.N.)

INDIA
THEASIAN JOURNALOF HORTICULTURE

Volume 12 Issue 2 | December, 2017 | 198-20

Visit us -www.researchjournal.co.in
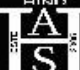

RESEARCH PAPER

DOI : 10.15740/HAS/TAJH/12.2/198-201

\section{Effect of different planting density on growth parameters of moringa (Moringa oleifera Lam.)}

\section{K. RAMKUMAR AND S. ANUJA ${ }^{1}$}

ABSTRACT : The present study effect of different planting density on growth parameters of moringa for leaf production (Moringa oleifera Lam.) was carried out during (Feb.- Dec.) 2016 in the vegetable field unit, Department of Horticulture, Faculty of Agriculture, Annamalai University, Annamalai Nagar. The treatment consisted of five different planting density viz., $\mathrm{T}_{1}$ $(45 \times 45 \mathrm{~cm}), \mathrm{T}_{2}(60 \times 60 \mathrm{~cm}), \mathrm{T}_{3}(75 \times 75 \mathrm{~cm}), \mathrm{T}_{4}(90 \times 90 \mathrm{~cm})$ and $\mathrm{T}_{5}(120 \times 120 \mathrm{~cm})$. Among the five different treatments, the treatment $T_{5}(120 \times 120 \mathrm{~cm})$ recorded highest value for plant height, number of branches, number of leaves and stem girth.

KEY WORDS : Spacing, Plant height, Stem girth, Number of leaves, Number of branches

HOW TO CITE THIS ARTICLE : Ramkumar, K. and Anuja, S. (2017). Effect of different planting density on growth parameters of moringa (Moringa oleifera Lam.). Asian J. Hort., 12(2) : 198-201, DOI : 10.15740/HAS/TAJH/12.2/198-201. 